\title{
Factores ambientales y parámetros genéticos para algunas características reproductivas en bovinos Chacuba
}

\section{Environmental factors and genetic parameters for some reproductive traits in Chacuba cattle}

\author{
José Luis Espinoza Villavicencioa, Ángel Ceró Rizob, Danilo Guerra Iglesiasc, Alejandro \\ Palacios Espinosaa, J oel Domínguez Viverosd, Dianelys González-Peña Fundorae
}

\begin{abstract}
RESUMEN
El objetivo del estudio fue analizar el impacto de factores ambientales, así como estimar componentes de (co)varianza de caracteres reproductivos en el bovino Chacuba. Para ello se utilizaron 4,957 registros de vacas, hijas de 893 madres y 110 sementales. Se probaron modelos que consideraron el número de parto, el sexo del becerro y los grupos de contemporáneas (hato-año-época de parto) como efectos fijos. La época de parto se incluyó como bimestre, trimestre, cuatrimestre o semestre. Los caracteres intervalo parto concepción (IPC), intervalo entre partos (IP) y servicios por concepción (SC) se analizaron con un modelo univariado y multivariado utilizando el programa ASReml. El número de parto $(\mathrm{P}<\mathbf{0 . 0 1})$ y los grupos de contemporáneas $(\mathrm{P}<\mathbf{0 . 0 0 1})$ afectaron significativamente las características reproductivas. Sin embargo, el sexo del becerro $(P>0.05)$ no fue un efecto significativo. Las heredabilidades para los rasgos analizados fueron bajas con valores de $0.14 \pm 0.02,0.15 \pm 0.02$ y $0.04 \pm 0.01$ para IPC, IP y SC, respectivamente. Las correlaciones genéticas fueron altas entre IPC e IP $(0.99 \pm 0.43)$ pero bajas entre IPC y SC (0.10 0.14$)$ y entre IP y SC (0.09 \pm 0.11$)$. Los modelos de estimación de parámetros genéticos para IPC, IP y SC en vacas Chacuba deben considerar el número de parto y los grupos de contemporáneas que incluyan hato-año-bimestre. La selección indirecta para el intervalo entre partos a partir del intervalo parto-concepción puede ser implementada, dada la correlación genética entre estos caracteres.
\end{abstract}

PALABRAS CLAVE: Bovino Chacuba, Heredabilidad, Correlaciones genéticas, Intervalo entre partos, Intervalo partoconcepción, Servicios por concepción.

\begin{abstract}
The aim of the study was to analyze the impact of environmental factors as well as to estimate components of (co) variance of reproductive traits in Chacuba cattle. For that, 4,957 records of cows, daughters of 893 dams and 110 sires were used. Models that considered number of parity, calf sex, and contemporary group (herd-year-season of calving) as fixed effects were tested. The season of calving was included as every two, three, four and six months. The interval from calving to conception (ICC), calving interval ( $\mathrm{Cl}$ ), and services per conception (SC) were the traits analyzed with uni and multitrait models using the software ASReml. The parity $(P<0.01)$ and the contemporary groups $(P<0.01)$ significantly affected the reproductive traits; however, the calf sex $(P>0.05)$ was not. The heritability for the traits analyzed were low with values of $0.14 \pm 0.02,0.15 \pm 0.02$ and $0.04 \pm 0.01$ for ICC, $\mathrm{Cl}$ and $\mathrm{SC}$, respectively. Genetic correlations were high between ICC and $\mathrm{Cl}(0.99 \pm 0.43)$ but low between ICC and SC (0.10 \pm 0.14$)$ and between $\mathrm{Cl}$ and $\mathrm{SC}(0.09 \pm 0.11)$. Genetics parameters estimation models for the traits ICC, $\mathrm{Cl}$, and $\mathrm{SC}$ for $\mathrm{Chacuba}$ cows should consider parity and herd-year-quarter contemporary groups. Indirect selection for the calving interval using the interval calving-conception, can be implemented given the genetic correlation between these traits.
\end{abstract}

KEY WORDS: Chacuba, Heritability, Genetic correlation, Calving to conception, Calving interval, Services per conception.

\footnotetext{
Recibido el 31 de octubre de 2014. Aceptado el 3 de febrero de 2015.

a Universidad Autónoma de Baja California Sur, México. Carretera al Sur; km 5.5, La Paz, 23080 B.C.S. México. jlvilla@uabcs.mx. Correspondencia al primer autor.

Universidad de Camagüey, Cuba.

Centro de Investigación para el Mejoramiento Animal de la Ganadería Tropical. La Habana, Cuba.

Universidad Autónoma de Chihuahua, México.

e Universidad de Illinois, USA.
} 
El desempeño reproductivo de bovinos para carne en el trópico es afectado por factores ambientales, generalmente asociados con la condición corporal al parto y su dinámica durante el periodo posparto(1). El intervalo entre el parto y el reinicio de la actividad ovárica puede ser un obstáculo importante para la mejora de la eficiencia reproductiva, ya que es el principal responsable del aumento del intervalo entre partos(2), que es influenciado por la raza, nutrición, producción de leche, presencia del becerro, estación del año, presencia del semental(3) y el número de parto(4).

El ganado Cebú es reconocido por su habilidad para adaptarse a las condiciones del trópico que se encuentran restringidas para muchas razas de ganado Bos taurus(5). Con base en lo anterior, desde 1967 en Camagüey, provincia de Cuba se empezó a forjar el proyecto genético del grupo racial Chacuba que deriva del cruzamiento inter se de bovinos 5/8 Charolais 3/8 Cebú cubano. Sin embargo, aunque se ha generado conocimiento en torno a su genética y comportamiento, la difusión ha sido limitada.

Aunque la mayoría de los programas de mejoramiento genético en bovinos para carne enfatizan características relacionadas con el peso de los animales, la inclusión de rasgos reproductivos es importante(6). Los rasgos usados para medir la eficiencia reproductiva tienen una base genética importante, aunque en el ganado cebuino, la mayoría de ellos poseen un índice de herencia bajo(7). Uno de los indicadores para evaluar dicha eficiencia en bovinos es el intervalo entre partos. Sin embargo, este parámetro hace un diagnóstico tardío de la fertilidad; cuando se identifica un intervalo excesivo entre partos, la disminución de la productividad es un hecho consumado(4). Otra medida para valorar la eficiencia reproductiva del ganado bovino son los días abiertos, además, la obtención de información requiere menos tiempo; por tal motivo, su uso se justifica en la selección para mejorar el comportamiento reproductivo(8). Dado que los
Reproductive performance of beef cattle in the tropics is affected by environmental factors usually associated with body condition at calving and their dynamics during the postpartum period(1). The interval between calving and the resumption of ovarian activity can be a major obstacle to the improvement of the reproductive efficiency, as it is responsible for the calving interval(2), which is influenced by breed, nutrition, milk production, presence of the calf, season of the year, presence of the sire $(3)$ and number of calving(4).

Zebu cattle is recognized for its ability to adapt to tropical conditions, that are generally restricted for many Bos taurus breeds(5). Based on the foregoing, since 1967 in Camagüey, province of Cuba began to forge a genetic project of the racial group Chacuba which derives from the inter se crossing of bovines 5/8 Charolais 3/8 Cuban Zebu. However, although it has generated knowledge about genetics and performance, the spread has been limited.

Although the majority of beef cattle genetic improvement programs emphasize characteristics related to the weight of animals, the inclusion of reproductive traits is important(6). The traits used to measure reproductive efficiency have an important genetic basis, although in cattle, most of them have a low heritability(7). One of the indicators for assessing the efficiency in cattle is the calving interval. However, this parameter makes a late fertility diagnosis; when identifying an excessive calving interval, the decrease in productivity is an accomplished fact $(4)$. Another measure to assess the reproductive efficiency of beef cattle is the days open, and as the proper information requires less time, its use is justified in selection to improve the reproductive performance ${ }^{(8)}$. Since the days open are measured repeatedly in the animal's' life, it is important to know their genetic relationship with other reproductive features as the number of services per conception and calving interval(9).

Few years ago, genetic parameters and environmental factors affecting reproductive 
días abiertos se miden repetidamente en la vida del animal es importante conocer su relación genética con otros rasgos reproductivos como el número de servicios por gestación y el intervalo entre partos $(9)$.

Hasta hace pocos años, no se habían estudiado los parámetros genéticos y factores del ambiente que afectan los rasgos reproductivos del genotipo Chacuba. Dicho problema se tuvo que resolver para llevar a cabo la selección de los progenitores. Por lo anterior, el objetivo del presente estudio fue estimar parámetros genéticos y el efecto de factores ambientales que afectan la expresión de rasgos utilizados para medir la eficiencia reproductiva del bovino Chacuba.

El estudio se realizó tomando la información de bovinos de la Empresa Genética Rescate de Sanguily en la provincia de Camagüey, Cuba, cuyo objetivo fundamental es la producción de sementales para todo el país. Tiene un área total de $12,359.8$ ha con un área agrícola utilizable de 11,774.7 ha, de las cuales 8,855.8 están dedicadas a los pastos y forrajes.

El clima se comporta con dos estaciones bien definidas. Un período poco lluvioso que se extiende desde noviembre hasta abril y otro lluvioso que abarca de mayo a octubre. El período lluvioso no es homogéneo y está compuesto por dos épocas, en los bimestres de mayo a junio y septiembre a octubre, separados por un mínimo de precipitaciones en julio-agosto; la temperatura promedio oscila de

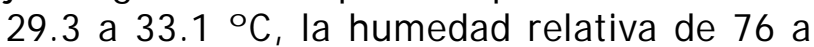
$84 \%$ con precipitaciones que varían de 20 a $240 \mathrm{~mm}(10)$.

El ganado se explota en condiciones de pastoreo todo el año. Se alimenta con pastos naturales como Tejana (Paspalum notatum) y Camagüeyana (Bothriochloa pertusa) y pastos cultivables de guinea (Panicum maximum) y estrella (Cynodon nlemfluensis); disponen también de especies arbóreas como algarrobo (Albizia saman), piñón (Glyricidia sepium) y traits of the genotype Chacuba have not been studied. That problem had to be resolved to carry out parents' selection. Therefore, the objective of this study was to estimate genetic parameters and the effect of environmental factors that affect the expression of traits used for measuring the reproductive efficiency of the Chacuba cattle.

The study was conducted taking information of 5/8 Charolais 3/8 Cebu and Chacuba (product of inter se crossbreeding of the former genotype) of the genetic rescue company of Sanguily in the Camagüey province, Cuba. The main objective of the company is the production of sires for the whole country. It has an area of $12,359.8$ ha with a usable agricultural area of $11,774.7 \mathrm{ha}$, of which $8,855.8$ are for pasture and forage.

The climate present two well-defined seasons: a dry season, which runs from November to April, and another rainy spanning from May to October. The rainy period is not homogeneous and is composed of two periods, in the 2-mo from May to J une and September to October, separated by a minimum of precipitation in JulyAugust; the average temperature ranges from 29.3 to $33.1{ }^{\circ} \mathrm{C}$, the relative humidity of 76 to $84 \%$ with rainfall ranging from 20 to 240 $\mathrm{mm}(10)$.

The cattle is exploited under grazing conditions throughout the year, with natural pastures as Tejana (Paspalum notatum) and Camagueyana (Bothriochloa pertusa) and cultivated grasses of guinea (Panicum maximum) and Star (Cynodon nlemfuensis). They have also trees such as carob (Albizia saman), sprocket (Glyricidia sepium) and gauge (Leucaena leucocephala) with some genera of native legumes (Centrosema, Desmodium and Calopogonium).

The breeding system utilize artificial insemination and natural rearing of the calf. Weaning was at $180 \mathrm{~d}$ of age until 1992 and from 1993, at 210 d. After the weaning period, females go to the 
guaje (Leucaena leucocephala) con algunos géneros de leguminosas nativas (Desmodium, Centrosema y Calopogonium).

El sistema de cría se basa en inseminación artificial y crianza natural del ternero. El destete se realizó a los 180 días de edad hasta 1992 y a partir de 1993, se hace a los 210 días.

En la etapa postdestete, las hembras pasan al centro de desarrollo y los machos a la prueba de comportamiento.

Se utilizaron los registros de 4,957 vacas nacidas en nueve hatos entre enero de 1980 y diciembre de 2004. Las vacas fueron hijas de 893 madres y 110 sementales. Los rasgos reproductivos evaluados fueron el intervalo entre el parto y la concepción (IPC), intervalo entre partos (IP) y los servicios por concepción (SC).

Para estimar los factores no genéticos que afectan el IPC, IP y los SC se aplicaron cuatro modelos matemáticos utilizando el procedimiento GLM del SAS(11). Los modelos tuvieron en común el genotipo de la hembra, el número del parto y el sexo de la cría. La diferencia entre los modelos estuvo en las combinaciones establecidas para la definición de grupos de contemporáneas (hato-año-época de parto), ya que para la época de parto se establecieron cuatro criterios de clasificación (bimestre, trimestre, cuatrimestre y semestre). De manera general el modelo utilizado fue:

$y_{i j k l m}=\mu+G C_{i}+S_{j}+G_{k}+N_{l}+e_{i j k l m}$

Donde: $\mathrm{y}_{\mathrm{ijk}} \mathrm{km}=$ variable dependiente (IPC, IP y $\mathrm{SC}) ; \mathrm{GC}_{\mathrm{i}}=$ grupo de contemporáneas del hatoaño- época de parto (nueve hatos; 1980 a 2004; bimestre, trimestre, cuatrimestre y semestre); $\mathrm{S}_{\mathrm{j}}=$ efecto fijo del sexo de la cría (macho; hembra); $G_{k}=$ efecto fijo del genotipo de la vaca (2; 5/8 Charolais 3/8 Cebú de primera generación y vacas producto del cruzamiento inter se de ese grupo genético); $\mathrm{N}_{l}=$ efecto fijo del número de parto (del primero al octavo parto); $\mathrm{e}_{\mathrm{ijklm}}=$ efecto del error aleatorio.
Development Centre and males to performance test.

Data consist of 4,957 records from cows born in nine herds between January 1980 and December 2004. The cows were daughters of 893 dams and 110 sires. The evaluated reproductive traits were the interval from calving to conception (ICC), calving interval $(\mathrm{Cl})$ and services per conception (SC).

To estimate the non-genetic factors that affect the ICC, $\mathrm{Cl}$ and the SC four mathematical models using the GLM procedure of SAS were applied(11). The models had in common the female genotype, the number of birth and the sex of the calf. The difference among the models was combinations established for the definition of contemporary groups (herd-year-calving season), since four classification criteria were established for occurrence of the calving season (bimester, trimester, quatrimester and semester). The general model used was:

$y_{i j k l m}=\mu+G_{i}+S_{j}+G_{k}+N_{l}+e_{i j k l m}$

Where: $\mathrm{y}_{\mathrm{ijk} k \mathrm{~m}}=$ dependent variable (ICC, $\mathrm{Cl}, \mathrm{SC}$ ); $\mathrm{GC}_{\mathrm{i}}=$ group of contemporaries of herd-yearcalving season (nine herds; 1980-2004; bimester, trimester, quarter, and semester); $\mathrm{S}_{\mathrm{j}}=$ fixed effect of the sex of calf (male, female); $\mathrm{G}_{\mathrm{k}}=$ fixed effect of the genotype of the cow (2; $5 / 8$ Charolais 3/8 Zebu of first generation and cows product of the inter se crossbreeding of that genetic group); $\mathrm{N}_{l}=$ fixed effect of the number of calving (from the first to the eighth); $\mathrm{e}_{\mathrm{ijk} / \mathrm{m}}=$ effect of the random error.

To obtain the variance components, analyses were performed with the ASReml program(12) and structured in the following way:

Analysis uni-character. Each character was studied as a separate feature. The mathematical model in matrix notation was:

$\mathrm{y}=\mathrm{Xb}+\mathrm{Za}+\mathrm{e}$

Where: $y=$ is the vector of observations for the trait in study; $b=$ vector of fixed effects that 
Para obtener los componentes de varianza, los análisis se realizaron con el programa ASReml(12) y estructurados de la siguiente forma:

Análisis unicarácter. Se estudió cada carácter como un rasgo independiente. El modelo matemático en notación matricial quedó de la siguiente forma:

$\mathrm{y}=\mathrm{Xb}+\mathrm{Za}+\mathrm{e}$

Donde: $y=$ es el vector de las observaciones para el rasgo en estudio; $b=$ vector de los efectos fijos que contienen el efecto de hatoaño-época de parto seleccionada previamente, el genotipo de la hembra, el número de parto y el sexo de la cría; $a=$ vector de los efectos aditivos aleatorios del animal; $\mathrm{e}=$ vector de los efectos residuales aleatorios; $\mathrm{X}, \mathrm{Z}=$ matrices de incidencia que relacionan a los efectos fijos y los efectos aleatorios aditivos del animal, respectivamente.

Análisis multicaracter. El modelo se representa en notación matricial como sigue:

$$
\left[\begin{array}{l}
\mathbf{y}_{1} \\
\mathbf{y}_{2} \\
\mathbf{y}_{3}
\end{array}\right]=\left[\begin{array}{ccc}
\mathbf{X}_{1} & \mathbf{0} & \mathbf{0} \\
\mathbf{0} & \mathbf{X}_{2} & \mathbf{0} \\
\mathbf{0} & \mathbf{0} & \mathbf{X}_{3}
\end{array}\right]\left[\begin{array}{l}
\mathbf{b}_{1} \\
\mathbf{b}_{2} \\
\mathbf{b}_{3}
\end{array}\right]+\left[\begin{array}{ccc}
\mathbf{z}_{1} & \mathbf{0} & \mathbf{0} \\
\mathbf{0} & \mathbf{Z}_{2} & \mathbf{0} \\
\mathbf{0} & \mathbf{0} & \mathbf{Z}_{3}
\end{array}\right]\left[\begin{array}{l}
\mathbf{a}_{1} \\
\mathbf{a}_{2} \\
\mathbf{a}_{3}
\end{array}\right]+\left[\begin{array}{l}
\mathbf{e}_{1} \\
\mathbf{e}_{2} \\
\mathbf{e}_{3}
\end{array}\right]
$$

Donde: $y_{i}=$ vector de las observaciones para el i-ésimo rasgo; $b_{i}=$ vector de los efectos fijos que contienen el efecto de hato-año-época de parto (seleccionado previamente), el genotipo de la hembra, el número de parto y el sexo de la cría para el i-ésimo rasgo; $a_{\mathbf{i}}=$ vector de los efectos aleatorios del animal para el i-ésimo rasgo; $e_{i}=$ vector de los efectos residuales aleatorios para el i-ésimo rasgo; $X_{i}$ y $Z_{i}$ son matrices de diseños que relacionan los datos con los efectos fijos y aleatorios, respectivamente.

Se asume que:

$$
\operatorname{var}\left[\begin{array}{l}
\mathrm{a}_{1} \\
\mathrm{a}_{2} \\
\mathrm{a}_{3} \\
\mathrm{e}_{1} \\
\mathrm{e}_{2} \\
\mathrm{e}_{3}
\end{array}\right]=\operatorname{var}\left[\begin{array}{cccccc}
\mathrm{g}_{11} \mathrm{~A} & \mathrm{~g}_{12} \mathrm{~A} & \mathrm{~g}_{13} \mathrm{~A} & 0 & 0 & 0 \\
\mathrm{~g}_{21} \mathrm{~A} & \mathrm{~g}_{22} \mathrm{~A} & \mathrm{~g}_{23} \mathrm{~A} & 0 & 0 & 0 \\
\mathrm{~g}_{31} \mathrm{~A} & \mathrm{~g}_{32} \mathrm{~A} & \mathrm{~g}_{33} \mathrm{~A} & 0 & 0 & 0 \\
0 & 0 & 0 & \mathrm{r}_{11} & \mathrm{r}_{12} & \mathrm{r}_{13} \\
0 & 0 & 0 & \mathrm{r}_{21} & \mathrm{r}_{22} & \mathrm{r}_{23} \\
0 & 0 & 0 & \mathrm{r}_{31} & \mathrm{r}_{32} & \mathrm{r}_{33}
\end{array}\right]
$$

contains the effect of herd-year-calving season selected previously, the genotype of the female, number of calving and the sex of the calf; $a=$ vector of random additive effects of the animal; $\mathrm{e}=$ vector of random residual effects; $\mathrm{X}, \mathrm{Z}$ : matrix of incidence that relates fixed effects and additive random effects of the animal, respectively.

Analysis multi-character. The model presents the following matrix notation:

$$
\left[\begin{array}{l}
\mathbf{y}_{1} \\
\mathbf{y}_{2} \\
\mathbf{y}_{3}
\end{array}\right]=\left[\begin{array}{ccc}
\mathbf{X}_{1} & \mathbf{0} & \mathbf{0} \\
\mathbf{0} & \mathbf{X}_{2} & \mathbf{0} \\
\mathbf{0} & \mathbf{0} & \mathbf{X}_{3}
\end{array}\right]\left[\begin{array}{l}
\mathbf{b}_{1} \\
\mathbf{b}_{2} \\
\mathbf{b}_{3}
\end{array}\right]+\left[\begin{array}{ccc}
\mathbf{Z}_{1} & \mathbf{0} & \mathbf{0} \\
\mathbf{0} & \mathbf{Z}_{2} & \mathbf{0} \\
\mathbf{0} & \mathbf{0} & \mathbf{Z}_{3}
\end{array}\right]\left[\begin{array}{l}
\mathbf{a}_{1} \\
\mathbf{a}_{2} \\
\mathbf{a}_{3}
\end{array}\right]+\left[\begin{array}{l}
\mathbf{e}_{1} \\
\mathbf{e}_{2} \\
\mathbf{e}_{3}
\end{array}\right]
$$

Where: $y i=$ vector of observations for the $i$-th feature; $b i=$ vector of fixed effects that contain the effect of herd-year-calving season (previously selected), the genotype of the female, calving number and the sex of the calf to the i-th feature; $a i=$ vector of random effects of the animal for the i-th feature; ei= vector of random residual effects for the i-th feature; $\mathrm{Xi}$ and $Z$ are matrix designs that relate data using fixed and random effects, respectively.

It assumes that:

$$
\operatorname{var}\left[\begin{array}{l}
\mathrm{a}_{1} \\
\mathrm{a}_{2} \\
\mathrm{a}_{3} \\
\mathrm{e}_{1} \\
\mathrm{e}_{2} \\
\mathrm{e}_{3}
\end{array}\right]=\operatorname{var}\left[\begin{array}{cccccc}
\mathrm{g}_{11} \mathrm{~A} & \mathrm{~g}_{12} \mathrm{~A} & \mathrm{~g}_{13} \mathrm{~A} & 0 & 0 & 0 \\
\mathrm{~g}_{21} \mathrm{~A} & \mathrm{~g}_{22} \mathrm{~A} & \mathrm{~g}_{23} \mathrm{~A} & 0 & 0 & 0 \\
\mathrm{~g}_{31} \mathrm{~A} & \mathrm{~g}_{32} \mathrm{~A} & \mathrm{~g}_{33} \mathrm{~A} & 0 & 0 & 0 \\
0 & 0 & 0 & \mathrm{r}_{11} & \mathrm{r}_{12} & \mathrm{r}_{13} \\
0 & 0 & 0 & \mathrm{r}_{21} & \mathrm{r}_{22} & \mathrm{r}_{23} \\
0 & 0 & 0 & \mathrm{r}_{31} & \mathrm{r}_{32} & \mathrm{r}_{33}
\end{array}\right]
$$

Where: gij = is the additive genetic variance for the $\mathrm{i}$-th trait, when $\mathrm{i}=\mathrm{j}$, and the genetic covariance when $i \neq j ; A=$ the relationship matrix. $\mathrm{rij}=$ is the residual variance when $\mathrm{i}=\mathrm{j}$, and the covariance when $i \neq j$.

Each trait was considered independent, but genetically and environmentally correlated with the others.

The overall average for ICC, $\mathrm{Cl}$ and SC appear in Table 1. Observed values of ICC or $\mathrm{Cl}$ are consistent with those referred in crosses Bos 
Cuadro 1. Media sin ajustar, desviación estándar (SD) y coeficiente de variación (CV) para el intervalo entre partos, intervalo parto-concepción, y servicios por concepción en ganado Chacuba

Table 1. Unadjusted mean, standard deviation (SD) and coefficient of variation (CV) for calving interval, interval calving-conception and services per conception in Chacuba cattle

\begin{tabular}{lccc}
\hline Rasgos & Mean & SD & CV (\%) \\
\hline Calving interval, days & 456 & 83 & 18.26 \\
Interval calving- conception, days & 168 & 83 & 49.32 \\
Services per conception, $n$ & 1.66 & 0.95 & 57.22 \\
\hline
\end{tabular}

Donde: $g_{i j}=$ es la varianza genética aditiva para la i-ésimo rasgo, cuando $i=j$ y, la covarianza genética cuando $i \neq j ; A=$ es la matriz de relaciones y $r_{i j}$ es la varianza residual cuando $\mathrm{i}=\mathrm{j} \mathrm{y}$, la covarianza cuando $\mathrm{i} \neq \mathrm{j}$.

Cada rasgo se consideró independiente, pero correlacionado genética y ambientalmente con los otros.

Las medias generales para el IPC, IP y SC aparecen en el Cuadro 1. Los valores observados de IPC o IP concuerdan con los referidos en cruzas de Bos taurus $x$ Bos indicus(4), cruzas de Nellore con distintas razas B. taurus o B. indicus(13), Chianina de Italia(14) y en la raza Cebú de Cuba(15). En ganado Cebú de Cuba(9) y en Simmental de México(16) se han reportado IPC e IP menos prolongados. Intervalos entre partos mayores que en el presente trabajo se estimaron en distintas cruzas de bovinos para carne en Colombia(17). Sin embargo, los valores obtenidos en este estudio fueron inferiores a otros reportes referidos en vacas Cebú $(15,18,19)$.

Los valores de IPC e IP fueron elevados, debido probablemente a deficiencias en el manejo reproductivo de los hatos, relacionadas con la detección de celos y alimentación de las vacas en el periodo pre y posparto(17).

Los resultados del análisis de varianza para el efecto del genotipo de la vaca y los factores no genéticos que afectaron el IPC, IP y SC se taurus $x$ Bos indicus(4), Nellore crosses with other B. taurus or B. indicus breeds(13), Chianina from Italy(14) and in Cuban Zebu breed(15). In Cuban Zebu cattle(9) and Simmental in Mexico(16) reported less prolonged ICC and $\mathrm{Cl}$. Calvings intervals higher than those in this work were estimated in different crosses of beef cattle in Colombia(17). However, the values obtained in this study were lower than other reports referred in Zebu cows $(15,18,19)$.

The ICC and $\mathrm{Cl}$ values were high, probably due to deficiencies in the reproductive management of herds, related to estrus detection and feeding of cows during the pre- and post-partum periods(17).

Table 2 shows the results from the analysis of variance for the effect of the genotype of the cow and the non-genetic factors that affected the ICC, $\mathrm{Cl}$ and SC. The genotype of the cow did not influence the evaluated reproductive traits $(P>0.05)$. The effect of the number of calving was significant $(P<0.01)$ for all the analyzed traits. In the first two calvings, cows presented longer $\mathrm{Cl}$ and the ICC decreasing until the eighth calving. This coincides with other studies that found less prolonged $\mathrm{Cl}$ and ICC intervals in animals between 5 and $9 \mathrm{yr}$ of age in cows Romosimuano(20) and Zebu(21). These results were associated as lactation and growth occur in parallel in early calvings, when females usually do not reach the adult size. Therefore, nutrients consumed during that period are for 
Cuadro 2. Efecto del genotipo de la vaca (G), número de parto (NP), sexo de la cría (SX) y grupo de contemporáneas, sobre algunos parámetros reproductivos en ganado Chacuba

Table 2. Effect of the genotype of the cow (G), parity (NP), sex of calf (SX) and contemporary group, on some reproductive parameters in Chacuba cattle

\begin{tabular}{lccccccccccccc}
\hline & \multicolumn{3}{c}{ Interval calving to conception } & \multicolumn{4}{c}{ Calving interval } & \multicolumn{4}{c}{ Services per conception } \\
\hline & M1 & M2 & M3 & M4 & M1 & M2 & M3 & M4 & M1 & M2 & M3 & M4 \\
G & 0.84 & 0.36 & 0.75 & 0.46 & 0.79 & 0.39 & 0.83 & 0.49 & 0.72 & 0.67 & 0.56 & 0.40 \\
NP & 0.01 & 0.01 & 0.01 & 0.01 & 0.01 & 0.01 & 0.01 & 0.01 & 0.01 & 0.01 & 0.01 & 0.01 \\
SX & 0.23 & 0.33 & 0.33 & 0.34 & 0.48 & 0.65 & 0.65 & 0.67 & 0.91 & 0.78 & 0.71 & 0.73 \\
\hline
\end{tabular}

M1= Contemporary group herd-year-calving bimester; M2= Contemporary group herd-year-calving trimester M3= Contemporary group herd-year-calving quatrimester; M4= Contemporary group herd-year-calving semester.

Probability values.

observan en el Cuadro 2. El genotipo de la vaca no influyó en los rasgos reproductivos evaluados $(P>0.05)$. El efecto del número de parto fue significativo $(P<0.01)$ para todos los rasgos analizados. En los dos primeros partos, las vacas presentaron los IPC e IP más prolongados para luego decrecer hasta el octavo parto. Lo anterior coincide con otros estudios en los que se encontraron IP e IPC menos prolongados en animales entre los 5 y 9 años de edad en hembras de la razas Romosimuano(20) y Cebú(21). Estos resultados fueron asociados a que el crecimiento y la lactación ocurren en paralelo en los primeros partos, ya que por lo general, el tamaño adulto de las hembras no se ha alcanzado. Por lo tanto, los nutrientes que consumen durante ese periodo pueden ser usados en mantenimiento, crecimiento y lactación, lo que afecta la fertilidad y provoca el alargamiento del anestro postparto. El argumento anterior coincide con un estudio en vacas Nelore de Brasil, en donde las vaquillas nulíparas tuvieron una mayor fertilidad que las vacas multíparas, y éstas a su vez que las de primer parto, atribuyendo el resultado a la mejor condición corporal durante el periodo de inseminaciones y a la ausencia del estrés que implica la lactancia(22). El sexo de la cría no afectó ninguna de las variables dependientes $(P>0.05)$. La ausencia de un efecto significativo del sexo de la cría sobre el IPC e IP coincide maintenance, growth, and lactation, which affects fertility and causes longer postpartum anestrus. The former argument agrees with a study in Brazil Nellore cattle, where nulliparous heifers showed a higher fertility than multiparous cows, and these in turn higher than those of the first calving, attributing the result to better body condition during the insemination period and the absence of stress involved in lactation(22). The sex of the calf did not affect any of the dependent variables $(P>0.05)$. The absence of a significant effect of the sex of the calf on the ICC and $\mathrm{Cl}$ coincides with reports in Romosinuano cows(20), Zebu(21) and double purpose(23).

The contemporary group affected $(\mathrm{P}<0.001)$ the ICC, $\mathrm{Cl}$ and SC. In general, the four classes of grouping (by bimester, trimester, quarter and semester of calving) have a major effect on each of the dependent variables mentioned. In another study conducted in Brazil(24) reproductive efficiency was affected by the season of the birth when it was divided into 20-d intervals throughout the year. The effect of period of calving on reproductive variables may be related to variation in the availability and quality of the pastures, which is associated in turn to body condition of cows giving birth and as a result the fertility in the postpartum period(25), affecting the CPI and the $\mathrm{Cl}(24)$. 
con reportes en vacas Romosinuano(20), Cebú(21) y de doble propósito(23).

El grupo de contemporáneas afectó $(P<0.001)$ el IPC, IP y SC. De manera general, las cuatro formas de agrupación de contemporáneas (bimestre, trimestre, cuatrimestre o semestre del parto) tienen un efecto importante sobre cada una de las variables dependientes señaladas. En otro estudio realizado en Brasil(24) la eficiencia reproductiva se afectó por la época de parto cuando ésta fue dividida en intervalos de 20 días a lo largo del año. El efecto de la época de parto sobre las variables reproductivas podría estar relacionada con la variación en la disponibilidad y calidad de lo pastos, la cual se asocia a su vez con la condición corporal de las vacas al parto y consecuentemente con la fertilidad en el periodo postparto(25), afectando el IPC y el IP(24).

En los cuatro modelos, el coeficiente de determinación $\left(R^{2}\right)$ para el IPC e IP fluctuó entre 31 y $38 \%$. Los valores de $R^{2}$ menores fueron para los SC en los cuatro modelos (entre 10 y $15 \%$ ). Los $\mathrm{R}^{2}$ de mayor valor en las tres variables dependientes corresponden al modelo que incluyó al grupo de contemporáneas hatoaño-bimestre. Los valores bajos en $\mathrm{R}^{2}$ registrados indican que las características de tipo reproductivo analizadas también son afectadas
In all four models, the coefficient of determination $\left(R^{2}\right)$ for ICC and $\mathrm{Cl}$ fluctuated between 31 and $38 \%$. The minor $\mathrm{R}^{2}$ values were for SC in the four models (between 10 and $15 \%)$. The $R^{2}$ value from the three dependent variables corresponds to the model that included a contemporary group of herdyear-bimester. The low $\mathrm{R}^{2}$ values recorded indicate that factors other than those included in the models affect the reproductive characteristics analyzed. In correspondence with the above results, the contemporary group of herd-year-bimester was included in the uni and multi-character models for estimation of variance components and genetic parameters.

Table 3 shows heritabilities for ICC, $\mathrm{Cl}$ and SC. The genetic parameters estimated for the reproductive traits using uni-character and multicharacter models were similar because of the low variance components for the additive genetic effect. That indicates that these features are predominantly influenced by environmental effects and the contribution of dominant genes or epistaxis, where the additive genetic variance contributes little in the total variance(26).

Most of the literature in dairy cattle agrees that heritability for such traits is equal to or less than 0.05, although for $\mathrm{Cl}$ reported also values of $0.19(26)$. In this sense, the literature on beef

Cuadro 3. Componentes de varianza y heredabilidades para el intervalo parto-concepción (CCI), intervalo entre partos (Cl) y servicios por concepción (SC) estimados mediante modelos unicarácter o multicarácter en ganado Chacuba

Table 3. Variance components and heritabilities for calving to conception interval (CCl), calving interval $(\mathrm{Cl})$ and services per conception (SC) estimated by uni-character or multi-character models in Chacuba cattle

\begin{tabular}{lrrrrrrr}
\hline & \multicolumn{5}{c}{ Model } \\
\hline & \multicolumn{3}{c}{ Uni-character } & & \multicolumn{3}{c}{ Multi-character } \\
\cline { 2 - 4 } \cline { 6 - 7 } Component & $\mathrm{CCl}$ & $\mathrm{Cl}$ & $\mathrm{SC}$ & & $\mathrm{CCl}$ & $\mathrm{Cl}$ & $\mathrm{SC}$ \\
\hline$\sigma^{2}$ additive & 949.37 & 966.16 & 0.04 & & 988.6 & 1005 & 0.04 \\
$\sigma^{2}$ error & 5636.77 & 5656.37 & 0.8456 & & 5622 & 5642 & 0.85 \\
$\sigma^{2}$ phenotypic & 6586.14 & 6622.53 & 0.89 & & 6610.6 & 6647 & 0.89 \\
Heredability & $0.14 \pm 0.02$ & $0.15 \pm 0.02$ & $0.05 \pm 0.01$ & & $0.15 \pm 0.02$ & $0.15 \pm 0.02$ & $0.04 \pm 0.01$ \\
\hline
\end{tabular}


por factores distintos a los incluidos en los modelos. En correspondencia con los resultados anteriores el grupo de contemporáneas hatoaño-bimestre fue incluido en los modelos uni y multicarácter para la estimación de componentes de varianza y parámetros genéticos.

Las heredabilidades para el IPC, IP y SC se presentan en el Cuadro 3. Los parámetros genéticos estimados para los rasgos reproductivos usando los modelos unicarácter y multicarácter fueron similares debido a la poca variación de los componentes de varianza para el efecto genético aditivo; eso indica que se trata de rasgos predominantemente influenciados por efectos ambientales y por la contribución de genes dominantes o epistásicos, donde la varianza genética aditiva contribuye poco en la varianza total(26).

La mayor parte de la literatura en el ganado lechero coincide en que la heredabilidad para este tipo de rasgos es igual o menor a 0.05 , aunque para el IP también se reportan valores de 0.19 (26). En este sentido, la literatura en bovinos para carne es más escasa. Los estimados de varianza aditiva y heredabilidad para el IPC en el presente estudio son similares a los referidos para la raza Asturiana de los Valles(8), en distintas cruzas de B. indicus $\times B$. taurus(17) y en Chianina(14). Sin embargo, los estimados son superiores a otros reportados en ganado Cebú Cubano(9) y en Santa Gertrudis(27). Resulta mayor también a los estimados que se reportan en ganado Girolando(28) y Cebú de Colombia(29). Un estimado de heredabilidad alto para el IP (0.42) fue reportado en vacas Nellore de Brasil(30). El valor de heredabilidad estimado para los SC en el presente trabajo coincide con algunos reportes en ganado Cebú(7).

Las correlaciones genéticas y ambientales entre el IPC y el IP fueron altas y positivas. Sin embargo, los SC mostraron una asociación genética baja y una relación ambiental moderada con el IPC e IP (Cuadro 4). Las correlaciones genéticas y ambientales entre IP cattle is scarce. Additive variance and heritability estimates for the ICC in this study are similar to those referred to the Asturiana de los Valles breed(8), in different crosses of B. indicus $\times$ B. taurus(17) and Chianina(14). However, the estimates are superior to others reported in Cuban Zebu cattle(9) and in Santa Gertrudis(27), and also for Girolando cattle(28) and Zebu of Colombia(29). An estimated high heritability for the $\mathrm{Cl}(0.42)$ was reported in Brazil Nellore cows (30). The value of heritability estimated for the SC in the present work coincides with some reports in Zebu cattle(7).

Genetic and environmental correlations between the ICC and the $\mathrm{Cl}$ were high and positive. However, SC showed a low genetic association and a moderate environmental relationship with the ICC and $\mathrm{Cl}$ (Table 4). Genetic and environmental correlation between $\mathrm{Cl}$ and ICC close to the unit indicates that the same genes and environmental factors affect the expression of both characteristics $(8,31)$. Estimates of genetic correlations between $\mathrm{Cl}$ and ICC are scarce. There are reported values of 0.98 in dairy cattle in New Zealand(32) and in Colombian Holstein(31). In the present study, the genetic and environmental correlations between ICC and $\mathrm{Cl}$ are the same as those reported in Cuban Zebu cattle ${ }^{(9)}$; however in that work the genetic correlation between the ICC and SC turned out to be higher than in the present.

Cuadro 4. Correlaciones genéticas (encima de la diagonal) y ambientales (debajo de la diagonal) entre el intervalo parto-concepción (ICC), intervalo entre partos (Cl) y servicios por concepción (SC) en ganado Chacuba

Table 4. Genetic correlations (on the diagonal) and environmental correlations (below the diagonal) among the interval calving-conception (ICC), calving interval (Cl) and services per conception (SC) in Chacuba cattle

\begin{tabular}{lccc}
\hline & ICC & Cl & SC \\
\hline ICC & & $0.99 \pm 0.43$ & $0.10 \pm 0.14$ \\
Cl & $0.99 \pm 0.41$ & & $0.09 \pm 0.11$ \\
SC & $0.41 \pm 0.21$ & $0.41 \pm 0.21$ & \\
\hline
\end{tabular}


e IPC cercanas a la unidad indican que los mismos genes y factores del ambiente afectan la expresión de ambas características $(8,31)$. Las estimaciones de correlaciones genéticas entre IP e IPC son escasas. Se han reportado valores de 0.98 en ganado lechero de Nueva Zelanda(32) y en Holstein de Colombia(31). En el presente estudio, las correlaciones genéticas y ambientales entre el IPC e IP son iguales a las reportadas en ganado Cebú de Cuba(9), sin embargo en ese trabajo la correlación genética entre el IPC y SC resultó mayor que en el presente.

En conclusión, la heredabilidad encontrada en este estudio para los rasgos reproductivos fue baja. Esto implica que se encuentran notablemente influenciados por el ambiente, por lo que se esperaría un progreso genético lento si se basa en la selección individual. Aún así, dada la correlación genética que existe, es factible la selección indirecta para el intervalo entre partos a partir del intervalo partoconcepción.

\section{LITERATURA CITADA}

1. Moura ICF, Kuss F, Moletta J L, de Menezes LF, Henrique D, Lipinski L, Martins A. Desempenho de vacas de corte PurunaP submetidas a diferentes manejos de amamentac'apo. Pesq Agropec Bras 2014;49(1):49-56.

2. Williams GL. Physiology and management of the postpartum suckled cow for controlled breeding programs. In: Williams GL, Forrest DW editors. Proc Applied reproductive strategies in beef cattle. Texas A\&M University, USA. 2005:184-196.

3. Miranda F, Wechsler S, Morais M, de Oliveira, Mendes AR, Rossi F. Reproductive efficiency of Nellore cows nursing Nellore or crossbred Simmental $\times$ Nellore calves. R Bras Zootec 2013;42(7):475-480.

4. Arellano S, Martínez J, Romero E, Briones F, Domínguez M, de la Garza F. Factores genético-ambientales que afectan el intervalo entre partos y días al primer parto del ganado de doble propósito en el norte de Veracruz. Rev AIA 2006; 10(1):43-53.

5. Turner JW. Genetic and biological aspects of Zebu adaptability J Anim Sci 1980;50(6)1201-1205.

6. Meirelles S, Espasandin AC, Mattar M, de Queiroz S. Genetic and environmental effects on sexual precocity traits in Nellore cattle. R Bras Zootec 2009;38(8):1488-1493.

7. Espinoza JL, Palacios A, de Luna R, Ávila N, Guerra D, González-Peña D et al. Componentes de (co)varianza para
In conclusion, the heritability found in this study for the reproductive traits was low. This implies that the environment greatly influences the reproductive traits, so, slow genetic progress is expected if it is only based on individual selection. Even so, given the genetic correlation that exists, allows the indirect selection for calving interval from the calving-conception period evaluation.

End of english version

caracteres de crecimiento y reproducción en ganado cebú en Cuba. Arch Zootec 2007;56(216):919-927.

8. Goyache F, Gutiérrez JP, Fernández I, Royo LJ, Álvarez I. Genetic analysis of days open in beef cattle. Livest Prod Sci 2005; 93(3): 283-289.

9. De Luna R, Guerra D, González-Peña D, Espinoza J L, Palacios A, Núñez R. Componentes de (co)varianza de caracteres reproductivos y su relación genética con el peso al destete en ganado Cebú de Cuba. Tec Pecu Mex 2008;46(3):225234.

10. CITMA. Diagnóstico ambiental de la cuenca del río San Pedro en Camagüey Cuba. Centro de investigaciones de medio ambiente de Camagüey. Ministerio de la Ciencia, Tecnología y Medio Ambiente de Cuba. La Habana, Cuba. 2003.

11. SAS. SAS/STAT User's Guide (Release 8.2). Cary NC, USA: SAS Inst. Inc. 2001.

12. Guilmour AR, Cullis BR, Erlham JS, Thompson R. ASREML Reference Manual. Australia: NSW Agriculture. 2000.

13. Perotto D, Abrahapo JJ, Kroetz IA. Intervalo de partos de femeas bovinas Nelore, Guzeraì $x$ Nelore, Red Angus $x$ Nelore, Marchigiana $x$ Nelore e Simental $x$ Nelore. R Bras Zootec 2006;35(3): 733-741.

14. Azevedo DM, Filho $\mathrm{R}$, Bozzi R, Forabosco $\mathrm{F}$, Malhado $\mathrm{CH}$. Parametros geneiticos e fenotiìpicos do desempenho reprodutivo de femeas Chianina. $\mathrm{R}$ Bras Zootec 2006; 35(3) 982-987.

15. Santana Y. Factores genéticos y no genéticos que afectan los caracteres reproductivos en la hembra Cebú [tesis maestría]. La Habana, CU: Centro de Investigaciones para el Mejoramiento Animal; 2004.

16. Montaldo HH, Núñez SG, Román-Ponce $S$, Ruiz-López $F$, Castillo-J uárez $\mathrm{H}$, Román-Ponce $\mathrm{H}$ et al. Crossbreeding effects for milk production and reproduction traits in a Multibreed cattle population in Mexico. World Cong Genetics Applied Livest Prod. Belo Horizonte, MG. Brasil. 2006.

17. Vergara O, Cerón M, Hurtado N, Arboleda E, Granada J, Rúa C. Estimación de la heredabilidad del intervalo de partos en bovinos cruzados. Rev MVZ Córdoba 2008;13(1):11921196.

18. Falcón R, Guerra, D, Veliz D, Santana Y, Rodríguez M, Ortiz $\mathrm{J}$. Estudio de los factores genéticos y ambientales que influyen sobre algunos índices reproductivos en novillas de 
la raza Cebú. Congreso internacional sobre mejoramiento animal. La Habana, Cuba. 2005:1098-1102.

19. Guerra D, González-Peña D, Rodríguez M, Planas T, Ramos F. Estimación de componentes de (co)varianzas de rasgos de crecimiento y reproductivos en el ganado Cebú Cubano. Congreso internacional sobre mejoramiento animal. La Habana, Cuba. 2005:1070-1072.

20. Ossa $G$, Suárez $M$, Pérez J. Factores ambientales y genéticos relacionados con el intervalo entre partos en la raza Romosinuano. Rev MVZ Córdoba 2006;11(2):799-805.

21. Magaña J, Delgado R, Segura J. Factores ambientales y genéticos que influyen en el intervalo entre partos y el peso al nacer del ganado Cebú en el sureste de México. Rev Cubana Cienc Agríc 2002;36(4):317-322.

22. Batista D, de Abreu U, Ferraz P, Rosa A. Índices reprodutivos do rebanho Nelore da fazenda Nhumirim, Pantanal da Nhecolândia. Acta Scientiarum Anim Sci 2012;34(1):71-76.

23. Vergara OG, Botero L, Martínez C. Factores ambientales que afectan la edad al primer parto y primer intervalo de partos en vacas del sistema doble propósito. RevMVZ Córdoba 2009; 14(1): 1594-1601.

24. Reinher C, Jardim JO, Peripolli V, Rosa E, Andrighetto ME. Calving sub-season and reproductive efficiency of beef cows. R Bras Zootec 2010;39(10)2182-2186.

25. Piva JF, Menegaz AL, Gonc'alves AC. Pre- and post-calving forage systems and reproductive performance of primiparous cows. R Bras Zootec 2010;39(9):2081-2090.

26. Bertipaglia EC, Gomes da Silva R, Cardoso V, Campos AS. Estimativas de parametros geneiticos e fenotiìpicos de caracterìisticas do pelame e de desempenho reprodutivo de vacas holandesas em clima tropical. R Bras Zootec 2007; 36(2):350-359.

27. Guerra D, Espinoza JL, Palacios A, González-Peña D, Rodríguez F, Guillén A. Componentes de (co)varianza de los días abiertos en bovinos Santa Gertudis. Tec Pecu Mex 2009; 47(2): 145-155.

28. Facó O, Braga RN, Filho RM, Martins GA, Pinheiro SM, Machado DM. Efeitos genéticos aditivos e não-aditivos para características produtivas e reprodutivas em vacas mestiças Holandês x Gir. R Bras Zootec 2008;37(1):48-53.

29. Montes $D$, Vergara $O$, Prieto $E$. Una nota sobre la estimación de la heredabilidad del intervalo entre partos en hembras bovinas de ganado Brahman. Livest Res Rural Devel 2009;21(1). http://www.lrrd.org/lrrd21/1/mont21002.htm. Consultado 10 oct, 2014.

30. Silveira J, McManus C, Mascioli A, Silva LO, Silveira AC, García J A et al. Fatores ambientais e parametros geneiticos para caracteristicas produtivas e reprodutivas em um rebanho Nelore no Estado do Mato Grosso do Sul. R. Bras Zootec 2004;33(6): 1432-1444.

31. Zambrano JC, Echeverri J. Genetic and environmental variance and covariance parameters for some reproductive traits of Holstein and Jersey cattle in Antioquia (Colombia). R Bras Zootec 2014;43(3):132-139.

32. Grosshans T, Xu ZZ, Burton LJ, Johnson DL, MacMillan KL. Performance and genetic parameters for fertility of seasonal dairy cows in New Zealand. Livest Prod Sci 1997;51(13): 41-51. 
